\section{Role of endoscopy in chronic diarrhoea when functional bowel disease is suspected}

We thank Ong and colleagues ${ }^{1}$ for their comment on the indication for lower GI endoscopy when functional bowel disease such as IBS diarrhoea predominant (IBS-D) is suspected.

In most patients with chronic diarrhoea, some form of endoscopic investigation will be necessary. However, it has been recommended that in young patients (less than 40 years) reporting 'diarrhoea' but who have other typical symptoms of a functional bowel disorder and negative initial investigations including faecal calprotectin, a positive diagnosis of IBS-D may be made in the primary care setting without recourse to further investigations. ${ }^{2}$

We are concerned that many patients with severe, persistent or atypical symptoms fail to have other specific treatable diagnoses made. Hence, the guidelines subsequently clarify this further within section 4.2, to state 'patients under 40 years without typical symptoms of functional bowel disorder and/or severe symptoms and documented diarrhoea (as previously defined) should have further evaluation'. ${ }^{3}$ By this, we mean referral to specialist secondary care, which, usually will include lower GI endoscopic evaluation.

One of the reasons for this recommendation is that up to $10 \%$ of patients meeting the criteria for IBS-D actually have microscopic colitis (MC) ${ }^{4}$ and $25 \%$ of MC occurs under the age of $45 .^{5}$ This risk increases if patients have other concurrent autoimmune conditions. Flexible sigmoidoscopy will detect the majority of patients with microscopic pathology. ${ }^{6}$ Moreover, it should be noted that faecal calprotectin is often in the normal range in $\mathrm{MC} \cdot{ }^{78} \mathrm{~A}$ clinical scoring system can also be applied to predict risk of MC and guide indications for lower GI endoscopy. ${ }^{9}$ A further reason for secondary referral is to detect bile acid diarrhoea, which, occurs in over $25 \%$ of patients and is frequently missed. ${ }^{10}$

Clearly, clinical judgement needs to be applied in this large and varied group of patients, and this is especially true to identify those with severe, persisting or atypical symptoms who may need some additional investigation in order to identify treatable conditions. Naturally, this will require some reassessment of resources.

Ramesh P Arasaradnam 10 , 1,2,3,4 Julian R F Walters ${ }^{5}$

${ }^{1}$ Department of Academic Gastroenterology, University Hospital Coventry and Warwickshire, Coventry, UK
${ }^{2}$ Applied Biological Sciences, University of Coventry, Coventry, UK

${ }^{3}$ Warwick Medical School, University of Warwick, Warwick, UK

${ }^{4}$ University of Leicester, Leicester, UK

${ }^{5}$ Imperial College London, London, UK

Correspondence to Professor Ramesh P Arasaradnam, Department of Academic Gastroenterology, University Hospital Coventry \& Warwickshire, Coventry CV2 2DX, UK; r.arasaradnam@warwick.ac.uk

Contributors All authors have contributed equally.

Competing interests None declared.

Patient consent Not required.

Provenance and peer review Not commissioned; internally peer reviewed.

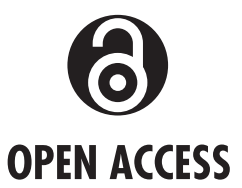

Open access This is an open access article distributed in accordance with the Creative Commons Attribution Non Commercial (CC BY-NC 4.0) license, which permits others to distribute, remix, adapt, build upon this work non-commercially, and license their derivative works on different terms, provided the original work is properly cited, appropriate credit is given, any changes made indicated, and the use is non-commercial. See: http://creativecommons.org/ licenses/by-nc/4.0/

(C) Author(s) (or their employer(s)) 2020. Re-use permitted under CC BY-NC. No commercial re-use. See rights and permissions. Published by BMJ.

\section{D) Check for updates}

To cite Arasaradnam RP, Walters JRF. Gut 2020:69:190-191.

Received 10 October 2018

Revised 7 November 2018

Accepted 7 November 2018

Published Online First 3 December 2018

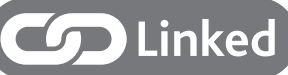

http://dx.doi.org/10.1136/gutjnl-2018-317574

Gut 2020;69:190-191. doi:10.1136/

gutjnl-2018-317730

\section{ORCID iD}

Ramesh P Arasaradnam http://orcid.org/0000-00022231-3062

\section{REFERENCES}

1 Ong J, Swift C, Allwood I, et al. Chronic diarrhoea: the indications for lower $\mathrm{Gl}$ endoscopy when functional bowel disease is suspected. Gut 2019;68:2100.

2 NICE. Irritable bowel syndrome in adults: diagnosis and management, 2017

3 Arasaradnam RP, Brown S, Forbes A, et al. Guidelines for the investigation of chronic diarrhoea in adults: British Society of Gastroenterology, 3rd edition. Gut 2018;67:1380-99.

4 Pardi DS, Kelly CP. Microscopic colitis. Gastroenterology 2011;140:1155-65.

5 Guagnozzi D, Arias Á, Lucendo AJ. Systematic review with meta-analysis: diagnostic overlap of microscopic colitis and functional bowel disorders. Aliment Pharmacol Ther 2016;43:851-62. 
6 Shale MJ, Walters JR, Westaby D. Adequacy of flexible sigmoidoscopy with biopsy for diarrhea in patients under age 50 without features of proximal disease. Gastrointest Endosc 2011;73:757-64.

7 McFarlane M, Chambers S, Malik A, et al. Clinical outcomes at 12 months and risk of inflammatory bowel disease in patients with an intermediate raised fecal calprotectin: a 'real-world' view. BMJ Open 2016;6:e011041.

8 von Arnim U, Wex T, Ganzert C, et al. Fecal calprotectin: a marker for clinical differentiation of microscopic colitis and irritable bowel syndrome. Clin Exp Gastroenterol 2016;9:97-103.

9 Cotter TG, Binder M, Harper EP, et al. Optimization of a scoring system to predict microscopic colitis in a cohort of patients with chronic diarrhea. J Clin Gastroenterol 2017:51:228-34.

10 Bannaga A, Kelman L, O'Connor M, et al. How bad is bile acid diarrhoea: an online survey of patientreported symptoms and outcomes. BMJ Open Gastroenterol 2017;4:e000116. 